\title{
The Evaluation of Skeletal Age Based on Computer-Supported Methods in Comparison to the Atlas Method
}

\author{
Anna Predko-Maliszewska ${ }^{1}$, Agnieszka Predko-Engel $^{2}$, Maciej Goliński $^{3}$ \\ 1 Department of Medical Informatics, University of Bialystok, Poland \\ 2 Department of Orthodontics, Palack'y University Olomouc, Czech Republic \\ 3 Department of Programming and Formal Methods, University of Bialystok, Poland
}

\begin{abstract}
This article describes methods used in estimating skeletal age based both on the evaluation of skeletal maturation of the palm and the wrist (Greulich and Pyle's atlas method) and the Cervical Vertebral Maturation method (CVM). The method of evaluating the skeletal age based on the measurement of cervical vertebrae with equations introduced by A. MachorowskaPieniążek is also mentioned. The article shows results obtained by computer analysis of the age of cervical vertebrae compared to the results gained from the implemented equations provided by A. Machorowska-Pieniążek and the results obtained from the atlas method.
\end{abstract}

\section{Introduction}

The estimation of human skeletal age is one of the ways of identifying the advancement of human biological development. Other characteristics taken into account while estimating the advancement of human biological maturity are: the development of secondary sexual characteristics, the age of first menstruation, voice change in the case of boys, the mineralization of teeth and their eruption, body mass and height. The estimation of biological maturity is widely used in pediatrics to estimate the child's development against the population and to possibly identify any deviations. It is also used in dentistry, allowing, for example, the right time of an orthodontic treatment to be chosen.

Bone age is not closely connected with the metrical age of a human. Among children of the same metrical age there can be significant differences in height and some of them may already have permanent teeth, while others may still have deciduous teeth. According to the time of maturing, the youth can be divided into early, moderately, and late maturing (Fish- 
man, 1987). The average age of the beginning of the maximal growth spurt is about 10 years for girls and 12 for boys, and after 2 years the peak of the growth spurt is reached (Hägg et al., 1980; Taranger et al., 1980). A large difference may also appear in the beginning of the maximal growth spurt, which usually occurs between the ages of 8 and 11 for girls, and 10 and 14 for boys (Fishman, 1987) and lasts about 5 years in both cases (Taranger et al., 1980).

\section{Methods Used in the Estimation of Skeletal Age}

The methods used in the estimation of skeletal age can be divided into two groups:

1. Those based on x-ray photos of the palm and the wrist

- The atlas method by Greulich and Pyle (Greulich et al., 1959)

- TW1-TW2-TW3 (Tanner et al., 1983)

- The method of the skeletal age estimation by Björk and Helm (Helm et al., 1971)

- The method by Hägg and Taranger (Hägg et al., 1980; Taranger et al., 1980)

- The method Skeletal Maturation Assessment (SMA) by Fishman (Fishman, 1987)

2. Those utilizing analysis of the shape and size of the cervical vertebrae based on the side photos (cephalograms) taken routinely before an orthodontic treatment. An important characteristic of cephalograms is that besides bone tissue, soft tissue is also visible in them. The photo also includes the cervical vertebrae.

- The method by Lamparski (1972) and its modifications, e.g.:

- CVMI - cervical vertebrae maturation index (Hassel et al., 1995)

- The Cervical Vertebral Maturation (CVM) - the estimation of the maturation of the cervical vertebrae by Baccetti, Franchi, and McNamara (Baccetti et al., 2002; 2005)

In this article, only the methods that were used in the examination are presented in detail.

The atlas method by Greulich and Pyle (Greulich et al., 1959) is a method based on the analysis of the development of the bones of the left palm and wrist. It consists of the comparison of an x-ray of the palm with the atlas photos and the choice of the most similar x-ray. This method allows the skeletal age to be determined. 
The beginnings of the works on the atlas reach back to the year 1931, and were connected to the research conducted under the direction of Prof. T. W. Todd. The research included a group of healthy children of the white race, and it consisted of making x-rays of the palm and the wrist. During the first year of life, the x-rays were taken every 3 months, after the first year and until the fifth year every 6 months, and then once a year.

The development of the palm and the wrist consists of many chronological changes until the final shape and size are reached. Working on the atlas, the norm for children in the given age was set based on 100 x-ray photos. Standards are separate for boys and girls.

The Cervical Vertebral Maturation method (CVM) developed by Baccetti et al. $(2002 ; 2005)$ is a modification of the Lamparski method. In the CVM method, only three cervical vertebrae are analyzed: C2, C3, C4.

Baccetti developed the scheme of the changes of the size and shape of the cervical vertebrae. In the initial phase, the C3 and C4 vertebrae are shaped like trapezoids, and the lower edge of the stem is flat. Next, on the lower edge of the vertebrae, a deepening concavity appears - first on C2, then $\mathrm{C} 3$, and finally on the $\mathrm{C} 4$ vertebra. At the same time, the shape of the vertebrae changes - gradually from a trapezium, through a rectangle with longer horizontal edges, than a square, to a rectangle with longer vertical edges.

Baccetti assigned 6 CVM phases (CS1 to CS6) to the changes in the shape and size of the cervical vertebrae. By identifying the CVM phase, it is possible to estimate the time of the maximal growth spurt. According to Baccetti, the growth spurt begins in the CS3 phase and ends in CS4. Table 1 presents the chronological scheme of the changes of the cervical vertebrae.

Table 1. Chronological scheme of the morphological changes of the C2, C3, and $\mathrm{C} 4$ vertebrae

\begin{tabular}{|c|c|c|c|}
\hline The CVM phase & The C2 vertebra & The C3 vertebra & The C4 vertebra \\
\hline CS1 & - The lower edge is flat & $\begin{array}{c}\text { The lower edge is flat } \\
- \text { The vertebra is simi- } \\
\text { lar in shape to a rect- } \\
\text { angular trapezium }\end{array}$ & $\begin{array}{c}\text { The lower edge is flat } \\
\text { lar in shape to a tra- } \\
\text { pezium }\end{array}$ \\
\hline CS2 & $\begin{array}{l}\text { - A concavity appears } \\
\text { on the lower edge }\end{array}$ & $\begin{array}{c}- \text { The lower edge is flat } \\
- \text { The vertebra is simi- } \\
\text { lar in shape to a rect- } \\
\text { angular trapezium }\end{array}$ & $\begin{array}{l}\text { The lower edge is flat } \\
\text { The vertebra is simi- } \\
\text { lar inape to a rect- } \\
\text { angular trapezium }\end{array}$ \\
\hline CS3 & $\begin{array}{l}\text { - There is an inden- } \\
\text { tation on the lower } \\
\text { edge }\end{array}$ & $\begin{array}{c}\text { A concavity appears } \\
\text { on the lower edge } \\
\text { The vertebra is simi- } \\
\text { lar in shape to a rect- } \\
\text { angular trapezium }\end{array}$ & $\begin{array}{c}\text { The lower edge is flat } \\
- \text { The vertebra is simi- } \\
\text { lar in shape to a rect- } \\
\text { angular trapezium }\end{array}$ \\
\hline
\end{tabular}


Anna Predko-Maliszewska, Agnieszka Predko-Engel, Maciej Goliński

\begin{tabular}{|c|l|c|c|}
\hline The CVM phase & The C2 vertebra & The C3 vertebra & The C4 vertebra \\
\hline \multirow{3}{*}{ CS4 } & $\begin{array}{l}\text { There is an inden- } \\
\text { tation on the lower } \\
\text { edge }\end{array}$ & $\begin{array}{l}\text { There is an inden- } \\
\text { tation on the lower } \\
\text { edge } \\
-\begin{array}{l}\text { The vertebra takes } \\
\text { the shape of a rect- } \\
\text { angle }\end{array}\end{array}$ & $\begin{array}{l}\text { A concavity appears } \\
\text { on the lower edge } \\
\text { The vertebra takes } \\
\text { the shape of a rect- } \\
\text { angle }\end{array}$ \\
\hline CS5 & $\begin{array}{l}\text { - There is an inden- } \\
\text { tation on the lower } \\
\text { edge }\end{array}$ & $\begin{array}{l}\text { - There is an indentation on the lower edge } \\
-\begin{array}{l}\text { Both vertebrae or only one take the shape of } \\
\text { a square }\end{array}\end{array}$ \\
\hline CS6 & $\begin{array}{l}\text { There is an inden- } \\
\text { tation on the lower } \\
\text { edge }\end{array}$ & $\begin{array}{l}\text { There is an indentation on the lower edge } \\
\text { Both vertebrae or only one take the shape of } \\
\text { a rectangle with longer vertical edges }\end{array}$ \\
\hline
\end{tabular}

A. Machorowska-Pieniążek (2011) undertook research concerned with identifying the sequences of the changes appearing in the cervical vertebrae. She selected a group of 256 boys and girls between the ages of 8 and 18 , receiving orthodontic treatment in the years 1993-2003 in the Department of Orthodontics, Department of Dentistry for Children and Adolescents in Zabrze, Medical University of Silesia in Katowice. The research consisted of making vertical and horizontal measurements of the $\mathrm{C} 2, \mathrm{C} 3$, and $\mathrm{C} 4$ vertebrae (Figure 1).

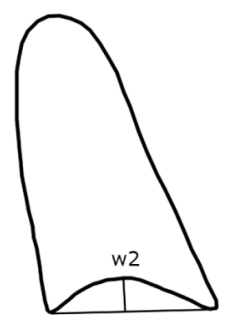

$2 \mathrm{w}$ - concavity of the lower border $2 \mathrm{CV}$

$3 \mathrm{a}-$ anterior hight $3 \mathrm{CV}$

$3 b$ - length of the lower border $3 \mathrm{CV}$

$3 \mathrm{c}-$ posterior hight $3 \mathrm{CV}$

$3 d$ - length of the upper border $3 \mathrm{CV}$

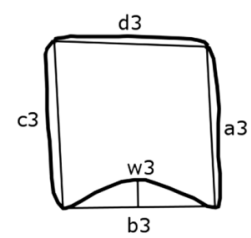

$3 \mathrm{w}$ - concavity of the lower border $3 \mathrm{CV}$

$4 \mathrm{a}$ - anterior hight $4 \mathrm{CV}$

$4 \mathrm{~b}$ - length of the lower border $4 \mathrm{CV}$

$4 \mathrm{c}-$ posterior hight $4 \mathrm{CV}$

$4 d$ - length of the upper border $4 \mathrm{CV}$

$4 \mathrm{w}$ - concavity of the lower border $4 \mathrm{CV}$

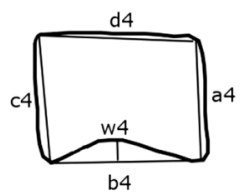

Figure 1. The vertical and horizontal measurements of the C2, C3, and C4 vertebrae 
The Evaluation of Skeletal Age Based on Computer-Supported Methods...

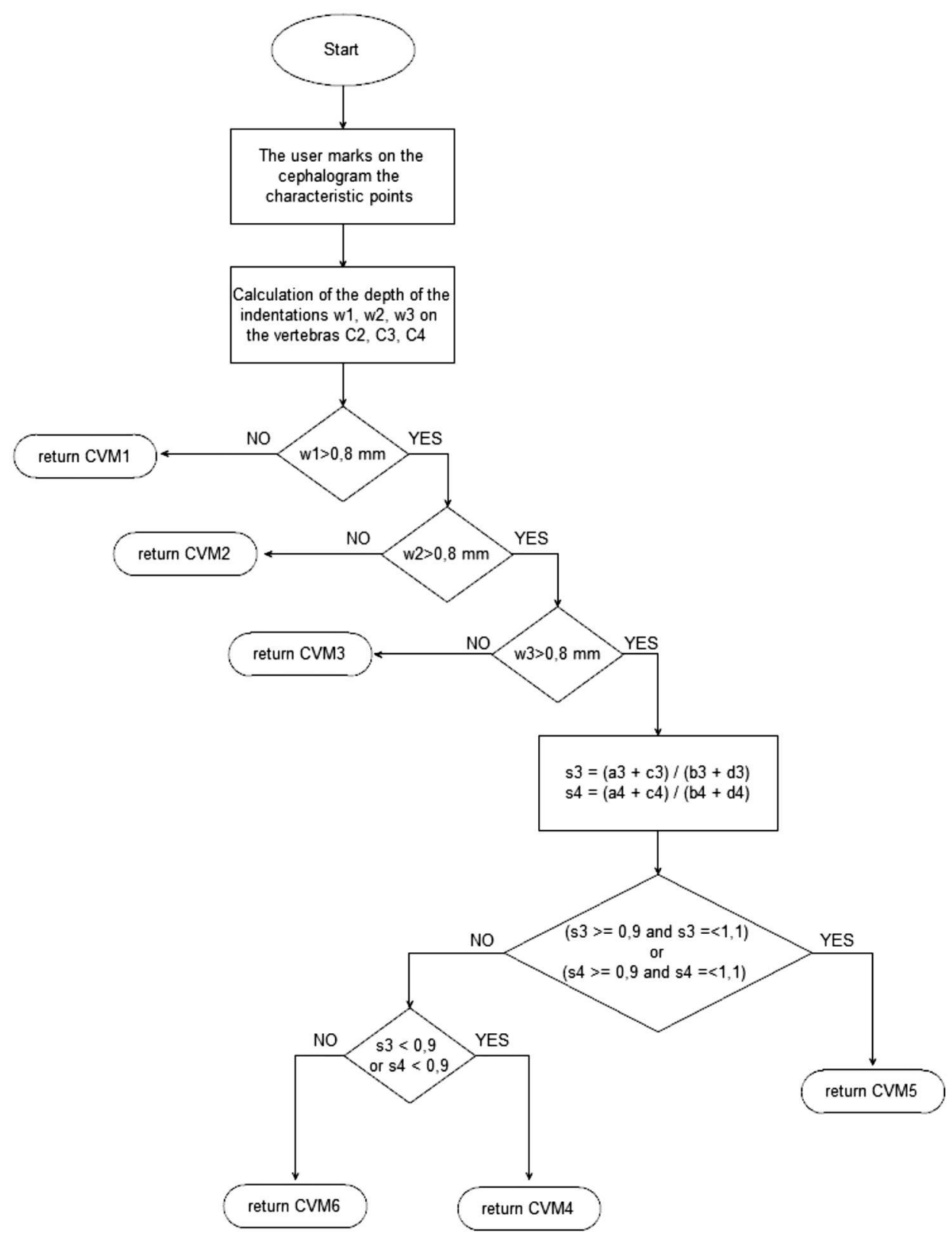

Figure 2. Algorithm identifying the CVM phase

The research showed that the horizontal dimensions of the C3 and $\mathrm{C} 4$ vertebrae among girls in the ages of 10 to 14 years, and boys to the age of 16, were larger then the vertical dimensions. Furthermore, the horizontal dimensions showed lower dynamics of growth than the vertical dimensions. 
The author, thanks to the undertaken research, derived a formula for the skeletal age for girls (1) and boys (2).

$$
\begin{aligned}
& C V M(K)=2.56+(0.36 \cdot 3 a)+(0.26 \cdot S W)+(0.09 \cdot 3 D) \\
& C V M(M)=3.41+(0.45 \cdot 4 a)+(0.42 \cdot S W)+(0.08 \cdot 3 D)
\end{aligned}
$$

where:

- $S W$ - the sum of the lower indentations of the C2, C3, and C4 vertebrae

$-3 D$ - the size of the $3 \mathrm{C}$ vertebra $(3 \mathrm{a}+3 \mathrm{~b}+3 \mathrm{c}+3 \mathrm{~d})$

Based on the Baccetti method, an algorithm for identifying the CVM phase was developed (Predko-Maliszewska et al., 2011). In the first step, the user marks the characteristic points on the cephalogram, i.e. the points delineating the lower edge on the $\mathrm{C} 2$ vertebra and the indentation on the base of the stem, and on the $\mathrm{C} 3$ and $\mathrm{C} 4$ vertebrae, the points delineating the upper, front, lower, and back edges of the stem, and also the indentations in the lower edges. Then, the algorithm determines the CVM phase according to Baccetti's procedure.

The scheme (Figure 2) presents the algorithm identifying the CVM phase. The notation refers to Figure 1.

Based on the calculations of the depth of the indentations on the lower edge of the cervical vertebrae and the length and width of the edges of the vertebrae obtained by the CVM phase identification algorithm, formulas (1) and (2) to calculate the skeletal age, provided by A. Machorowska-Pieniążek, were implemented.

\section{Material and Methods}

To compare the method of evaluating bone age based on the formulas developed by A. Machorowska-Pieniążek and the atlas method, based on the analysis of the x-ray photos of the palm and the wrist, a group of 44 patients (21 girls and 23 boys), receiving treatment in the Department of Orthodontics LF UP in Olomouc between 1.07.2004 and 11.03.2008, were studied. Table 2 contains the characteristics of the study group.

Every person from the study group was subjected by A. PredkoEngel to:

- the evaluation of skeletal age using the atlas method by Greulich and Pyle based on x-rays of the palm and the wrist,

- the identification of the CVM phase using the computer algorithm to evaluate the skeletal age based on the cervical vertebrae,

- the evaluation of skeletal age using the implemented formulas developed by A. Machorwska-Pieniążek. 
The Evaluation of Skeletal Age Based on Computer-Supported Methods...

Table 2. Characteristic of the study group

\begin{tabular}{|c|c|c|c|c|c|c|}
\hline \multicolumn{2}{|c|}{ Metrical age } & \multicolumn{2}{|c|}{ Girls } & \multicolumn{2}{c|}{ Boys } & \multirow{2}{*}{ Total } \\
\cline { 1 - 5 } Age group & Age range & Quantity & Mean age & Quantity & Mean age & \\
\hline 11 & $\langle 10,11)$ & 4 & 10.5 & & & 4 \\
12 & $\langle 11,12)$ & 6 & 11.5 & 5 & 11.6 & 11 \\
13 & $\langle 12,13)$ & 6 & 12.3 & 6 & 12.5 & 12 \\
14 & $\langle 13,14)$ & 5 & 13.7 & 3 & 13.1 & 8 \\
15 & $\langle 14,15)$ & & & 4 & 14.3 & 4 \\
16 & $\langle 15,16)$ & & & 5 & 15.3 & 5 \\
\hline Total & & 21 & & 23 & & 44 \\
\hline
\end{tabular}

\section{Results}

The obtained results allowed us to determine that a correlation between the evaluation using the atlas method and using the formula by A. Machorowska-Pieniążek exists (Table 3). At the same time, both methods show a correlation with the CVM phase using the algorithm for computer identification of the CVM phase.

Table 3. The correlation between used methods

\begin{tabular}{|l|c|c|c|}
\cline { 2 - 4 } \multicolumn{1}{c|}{} & $\begin{array}{c}\text { Atlas method / } \\
\text { implemented formulas by } \\
\text { A. Machorwska-Pieniążek }\end{array}$ & $\begin{array}{c}\text { Implemented formulas by } \\
\text { A. Machorwska-Pieniążek } \\
\text { / CVM phase }\end{array}$ & $\begin{array}{c}\text { Atlas method / CVM } \\
\text { phase }\end{array}$ \\
\hline $\begin{array}{l}\text { Correlation } \\
\text { - boys }\end{array}$ & 0.884048 & 0.768216 & 0.73584 \\
\hline $\begin{array}{l}\text { Correlation } \\
\text { girls }\end{array}$ & 0.787521 & 0.843425 & 0.694544 \\
\hline
\end{tabular}

However, a difference in the evaluation of the skeletal age exists using both methods. The obtained results allowed us to determine that the atlas method indicates a higher age compared to the age obtained using the method by A. Machorowska-Pieniążek (Figure 3, Figure 4).

The largest differences occurred in the estimation of the skeletal age for girls; smaller differences occurred in the group of boys. Among the girls, the highest noted difference was the value 3.8 years; in the case of the boys, it was 1.8 years. 
Anna Predko-Maliszewska, Agnieszka Predko-Engel, Maciej Goliński

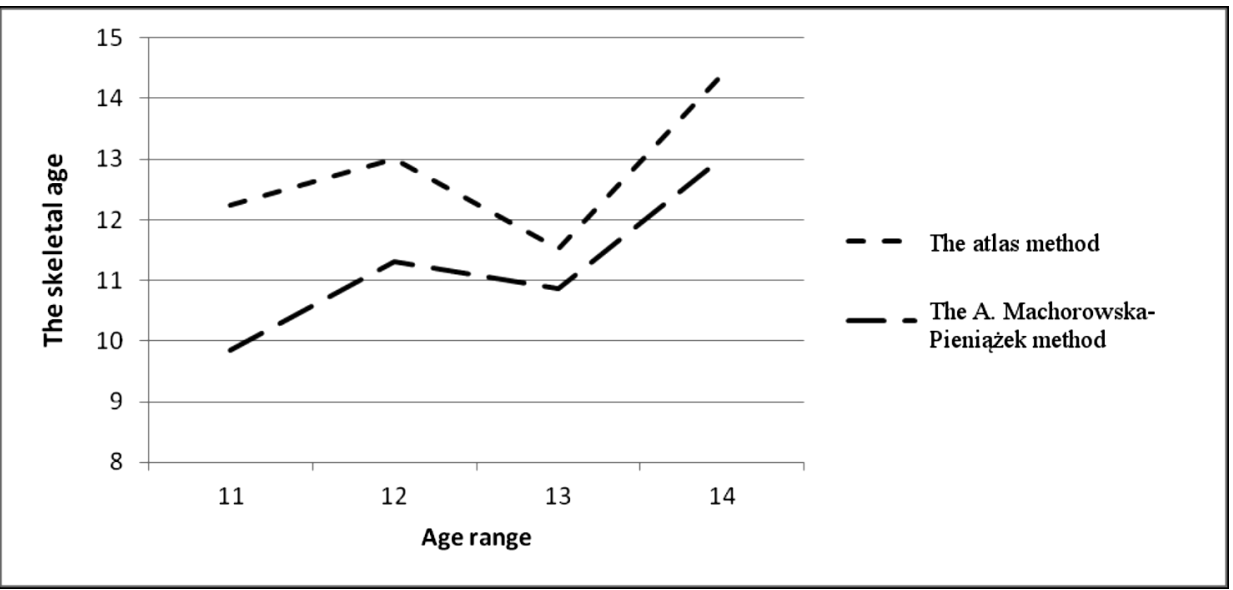

Figure 3. The skeletal age - girls

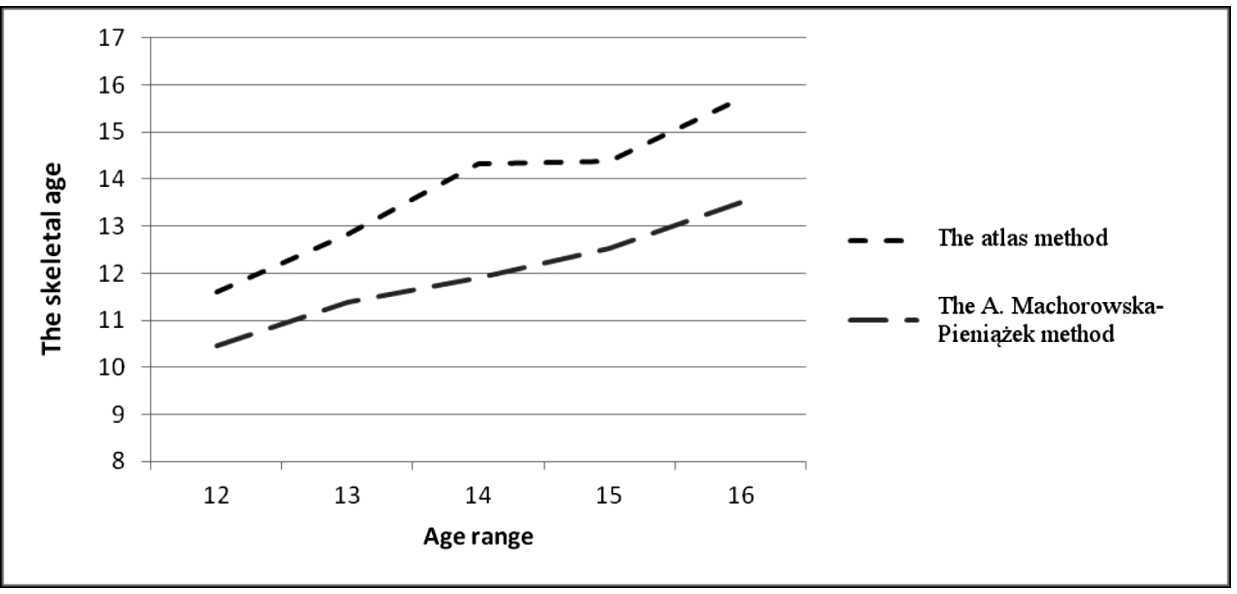

Figure 4. The skeletal age - boys

In the estimation of skeletal age for boys, the greatest differences have a value at $0.5-1$ year. For girls, the greatest differences have a value of 1-2 years or more (Table 4 ).

Table 4. The differences between the atlas method and the A. MachorowskaPieniążek method in the estimation of skeletal age

\begin{tabular}{|l|c|c|c|c|}
\cline { 2 - 5 } \multicolumn{1}{c|}{} & $\begin{array}{c}\text { Difference to } \\
0.5 \text { years }\end{array}$ & $\begin{array}{c}\text { Difference between } \\
0.5 \text { and 1 year }\end{array}$ & $\begin{array}{c}\text { Difference between } \\
1 \text { and 2 years }\end{array}$ & $\begin{array}{c}\text { Difference over } \\
2 \text { years }\end{array}$ \\
\hline Boys & $30.43 \%$ & $39.13 \%$ & $30.43 \%$ & - \\
Girls & $20.00 \%$ & $15.00 \%$ & $35.00 \%$ & $30.00 \%$ \\
\hline
\end{tabular}




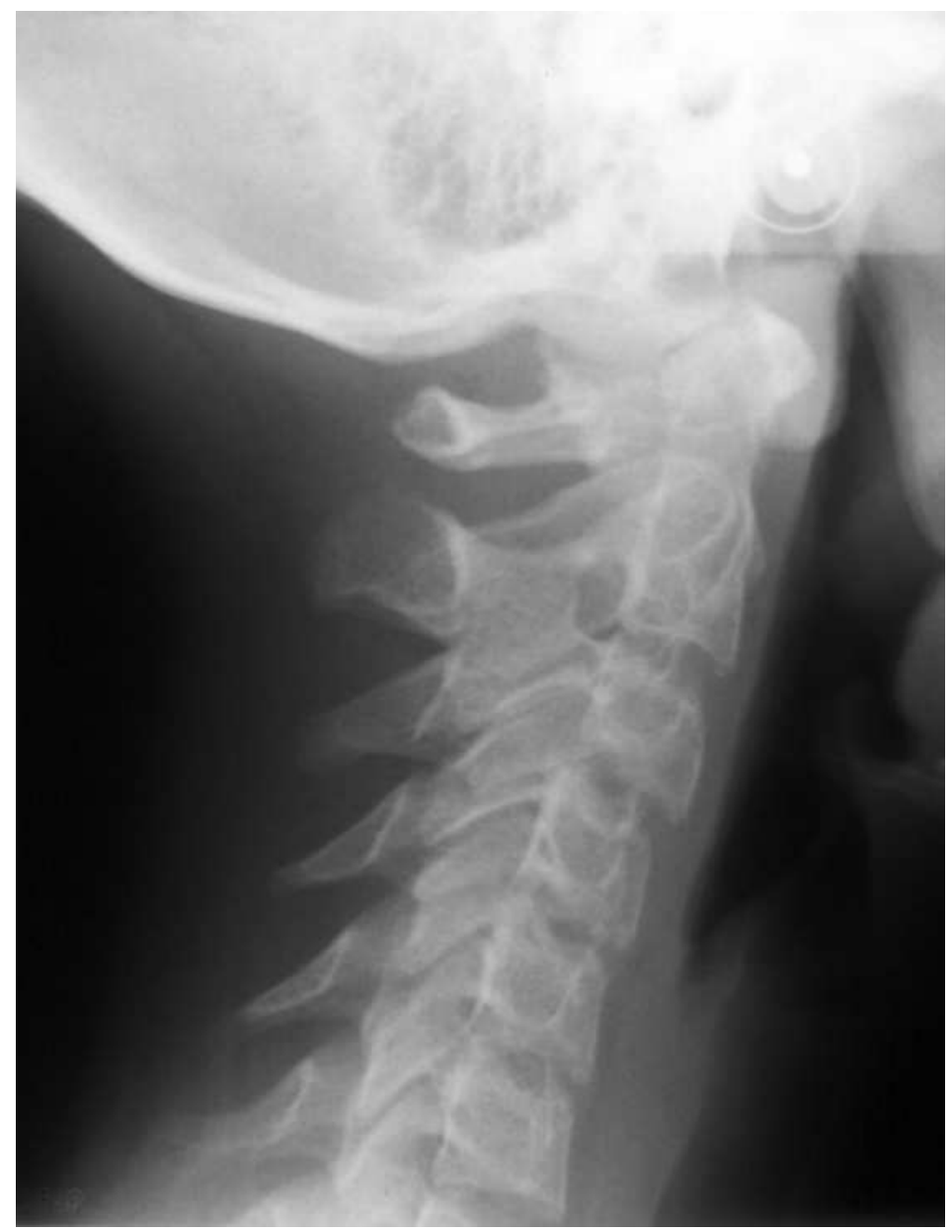

Figure 5. The cephalogram estimated for 11.2 years of skeletal age and the CVM phase 5

The greatest obtained difference in the estimation of the skeletal age in the girl population was found in the x-ray photos of the palm (Figure 6) and in the cephalograms (Figure 5) taken at the age of 11.9 years.

Using the atlas method, the skeletal age was estimated to be 15 years, using the implemented formula it was evaluated to be 11.2 years, while the CVM phase was estimated to be CS5. The difference between those two methods is 3.8 years. The cephalometric photo was an element of research used to determine the repetition of the estimation of the CVM phase (Predko-Engel et al., 2012). The research consisted of the double estimation of the CVM phase made by six doctors in the intervals from 2 weeks 


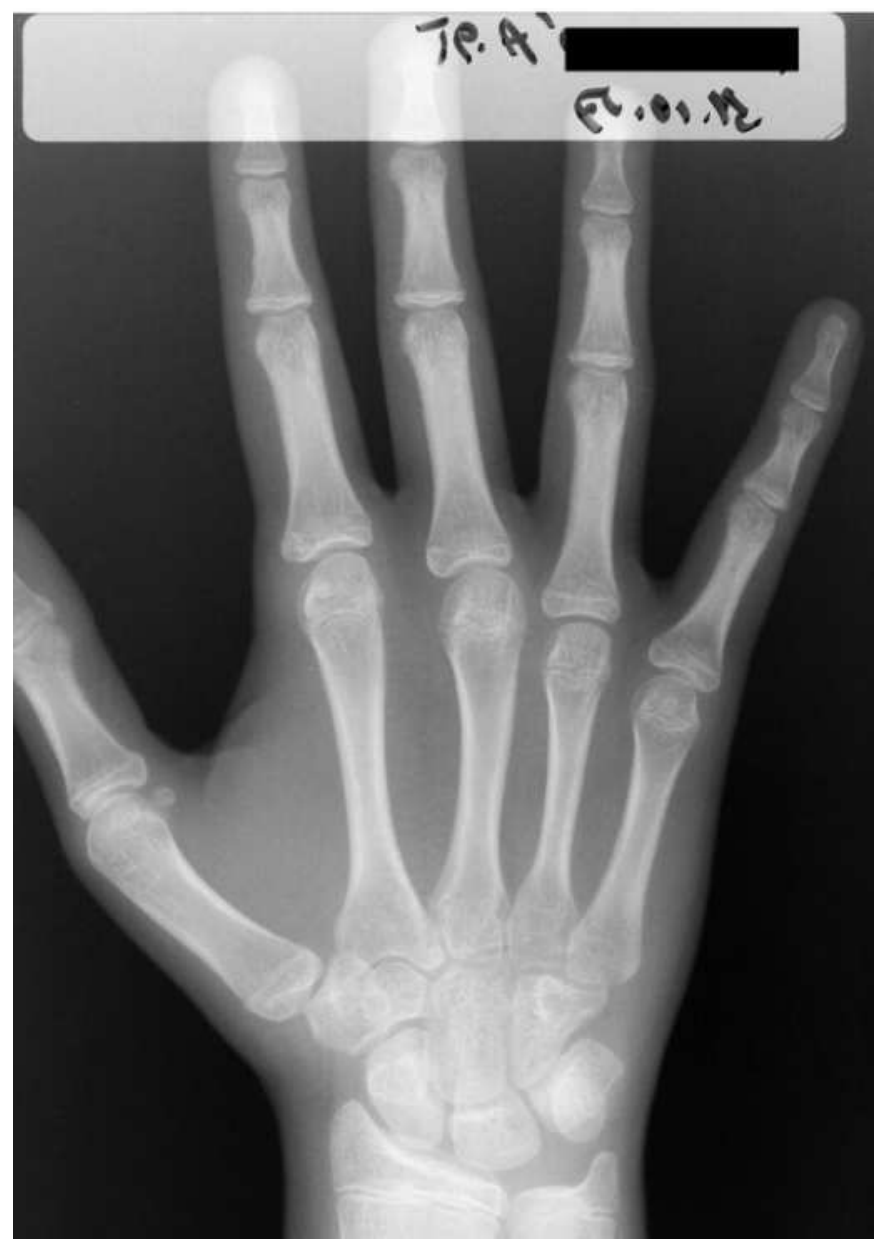

Figure 6. The x-ray of the palm and the wrist estimated for 15 years

to 2 months. The discussed photo was estimated to be in the phase CS1, CS5, CS6 in the first examination, and to be in the phase CS1, CS2, CS6 in the second one. In the first series, two researchers evaluated the photo to be in the CS1, and in the second one, to be in CS6.

\section{Discussion and Conclusions}

The analysis of the results allows us to conclude that both methods of evaluating skeletal age generate similar results. However, the implemented method by A. Machorowska-Pieniążek gives a lower result. In the case 
of boys, the differences are lower ( 0.8 years on average), and they are higher in the case of girls (1.4 years on average). The greatest differences between the results of both methods concern boys at the age of 14 years (1.4 years on average) and girls at 11-12 years (2 years on average). It is worth noting that in both the case of girls and boys, the age overlaps the time of the maximal growth spurt.

While analysing the obtained results, one should take into consideration the fact that the estimated skeletal age is important information for a doctor. An evaluation of the skeletal age that is incorrect by 2 years or more may lead to making wrong treatment decisions concerning the patient's plan of treatment and may eventually have a negative effect on the results of a treatment.

The method proposed by A. Machorowska-Pieniążek is based on the size of the cervical vertebrae and the depth of the indentation appearing on the cervical vertebrae. Those same elements are taken into consideration in the method provided by Baccetti with the evaluation of the CVM phase. Therefore, the evaluation using the implemented methods gives a high correlation. However, as it was shown (Predko-Engel et al., 2011), Baccetti's method doesn't correlate highly with Björk's method to estimate the time of the maximal growth spurt.

Also noteworthy is the earlier described case that was evaluated very differently by the researchers using the CVM method. The result provided by A. Machorowska-Pieniążek's method is also different from the evaluation using the atlas method in this case. The obtained difference is significant and is 3.8 years. It is also important that in $30 \%$ of the girls' cases, the results obtained by both methods provided differences over 2 years. In this case, A. Machorowska-Pieniążek's method should be recognized as one of the methods of evaluating skeletal age, but it cannot replace other used methods. In the cases where the effect of the treatment depends on the phase of the growth spurt, in which the treatment is undertaken or not, it is recommended to use a few methods of evaluation of the skeletal maturity, because none of the methods are distinctly more precise than the rest.

It should also be taken into consideration that the determination of the characteristic points is not very precise, and even a minimal shift of a point may change the result. However, this is more important in the case of evaluating the CVM phase, than estimating the skeletal age using A. Machorowska-Pieniążek's method. It is also due to the fact that in the developed algorithm of the evaluation of skeletal age using the CVM method, the shift of a characteristic point may result in the change of the proportions of the size of the vertebrae, or reduce or increase the concavity 
at the base of the vertebra, which may lead to the photo being qualified as a different CVM phase. In the case of the method by A. MachorowskaPieniążek, a minimal shift of the characteristic point changes the result only in the decimals.

\section{R E F E R E N C E S}

Baccetti, T., Franchi, L., \& McNamara, J. A. (2002). An improved version of the cervical vertebral maturation (CVM) method for the assessment of mandibular growth. The Angle Orthodontist, 72(4), 316-323.

Baccetti, T., Franchi, L., \& McNamara, J. A. (2005). The Cervical Vertebral Maturation (CVM) Method for the Assessment of Optimal Treatment Timing in Dentofacial Orthopedics. Seminars in Orthodontics, 11(3), 119-129. DOI:10.1053/j.sodo.2005.04.005.

Fishman, L. S. (1987). Maturation patterns and prediction during adolescence. The Angle Orthodontist, 57(3), 178-193.

Greulich, W. W., \& Pyle, S. I. (1959). Radiographic Atlas of Skeletal Development of the Hand and Wrist (2nd ed.). Stanford California: Stanford University Press.

Hägg, U., \& Taranger, J. (1980). Skeletal stages of the hand and wrist as indicators of the pubertal growth spurt. Acta Odontol Scand, 38(3), 187-200.

Hassel, B., \& Farman, A. G. (1995). Skeletal maturation evaluation using cervical vertebrae. Am J Orthod Dentofacial Orthop, 107(1), 58-66.

Helm, S., Siersbæk-Nielsen, S., Skieller, V., \& Björk, A. (1971). Skeletal maturation of the hand in relations to maximum puberal growth in body height. Tandlaegebladet (Danish Dental Journal), 75 (12), 1223-1234.

Lamparski, D. G. (1972). Skeletal age assessment utilizing cervical vertebrae (Master of Science thesis), University of Pittsburg. In S. J. Stiehl, Die Entwicklung der Halswirbel als Kriterium für die skelettale Reife: vergleich mit der klassischen Methode der Handwurzelaufnahme. Inaugural Dissertation Marburg an der Lahn, (2007).

Machorowska-Pieniążek, A. (2011). Morfometryczna ocena wieku kostnego, sekwencja zmian wzrostowych kręgów szyjnych. Dent Med Probl, 48(3), 335341.

Predko-Engel, A., Kamínek, M., \& Langová, K. (2011). Skeletální věk v ortodoncii. Čes. Stomatol, 111(6), 154-159.

Predko-Engel, A., Kamínek, M., Langová, K., \& Fudalej, P. (2012). Skeletal age according to cervical spine. Ortodoncie, 21(4), 218-226.

Predko-Maliszewska, A., \& Predko-Engel, A. (2011). Computer estimation of skeletal maturation on the basis of cervical vertebrae maturation, Studies In Logic, Grammar And Rhetoric, 25(38), 109-119. 
The Evaluation of Skeletal Age Based on Computer-Supported Methods...

Tanner, J. M., Whitehouse, R. H., Cameron, N., Marshall, W. A., Healy, M. J. R., \& Goldstein, H. (1983). Assessment of skeletal maturity and predictionof adult height (TW2 Method). London: Academic Press.

Taranger, J., \& Hägg, U. (1980). The timing and duration of adolescent growth. Acta Odontol Scand, 38(3), 57-67. 